\title{
From Experiment to Routine
}

Im letzten Jahrzehnt hat die niederländische Regierung mittels verschiedener Instrumente versucht, die freiwillige Einführung einer Integrierten Produktpolitik (IPP) durch die Unternehmen selbst voranzutreiben. Kernelement sind über 50 Pilotprojekte zu produktorientierten Umweltmanagementsystemen. Der Beitrag fasst die wichtigsten Ergebnisse dieser Projekte sowie weiterer Maßnahmen im Produktbereich zusammen. Abschließend werden die Umrisse der nun beginnenden nächsten IPP-Entwicklungsphase skizziert.

Von Henk Wijnen ntegrated Product Policy (IPP) was rather unknown and therefore not directly accepted when the Dutch government introduced the framework of it in 1993 (1). The goal was to start a process of continuously improving the environmental performance of products. Today the relative importance of products for environmental policy has been broadly acknowledged. The acceptance among all market actors is an important incentive for further disseminating IPP in more and other branches.

In the Netherlands IPP has been grounded on a voluntary approach because markets know better than government about the millions of different products. Market actors were indicated as responsible for this process. Industry should take the initiative, consumers should ask for environmental sound products and retailers should improve their stock environmentally. The role of the government was to stimulate, facilitate and, when necessary, to regulate.

Government has sought for a comprehensive and acceptable instrument together with industry. In 1993 information systems on environmental aspects of products were introduced. This instrument should be elaborated as either environmental labelling of consumer products or business-tobusiness information on materials or products. However, industry opposed fiercely against this instrument, especially regarding to the demand for providing information to the consumer. Therefore in 1996 governmental product policy was adjusted. The so-called Product-Oriented Environmental Management (POEM) system has been introduced as an extension of the ,normal“ environmental management system (EMS). This POEM idea was rather new and the possible outcome could not be precisely foreseen Due to the market conformity and the systematic approach embedded in the instrument, it was encountered by positive reactions of the industrial sector but by great scepticism from the environmental non governmental organisations (NGO's).

From 1997 to 1999 a pilot programme has been carried out to develop this product-oriented management tool in practice. More than 60 pilots in industry have been subsidised since 1997 . Experiences with POEM showed good results and the scepticism seems to disappear gradually. Government and industry are now working on the systematic introduction of POEM in many different industrial sectors. To enhance this dissemination, the subsidy programme has been extended for another five years.

\section{Differences between EMS and POEM}

POEM is considered as an implicit and integral part of a EMS but the 1998 interim evaluation of the first 43 pilot projects showed some remarkable differences. The main characteristics are:

a systematic EMS approach for products is only possible with the involvement of purchasers, R\&D department and marketing;

involvement of (all) parties of the product chain;

a strong involvement of management in POEM is necessary because the product is the core business of an enterprise (2).

Although those differences appear to be very important, the similarities between EMS and POEM are more striking. The cycle of plan - do - check - evaluate is the same for both and most of the ISO 14.001 content can be used without any problem to introduce a product oriented EMS.

Most of the pilot projects were done by individual companies and about twenty per cent at branch level. The main reason for the pilot programme was the purposeful development of the POEM system in practice. Only a framework based on three principles was laid down at the beginning of all pilots: Each pilot should contain a system, take into consideration environmental impacts from cradle to grave, and establish relations to other parts of the chain.

\section{Evaluation of 50 POEM pilots}

The evaluation study of 50 pilots showed the following results:

The main reason to start with POEM was a better insight in the environmental impact of their products and the product chain and to structure their own environmental policy.

- Subsidies emerged as a very positive stimulus towards implementation of POEM.

- A great difference was noticed between the incentives of medium sized companies and big companies. (Forthcoming) Environmental measures appeared to be the most important drive for medium sized companies, whereas big companies perceived POEM more as a strategic challenge reasoning future activities in the environmental field.

- Companies with an existing care or quality system tend to give better results in structuring a POEM system.

- Companies without a care or quality system used POEM as a starting point for a structured care system.

- There are two different development routes: either begin with the design of a system and then start specific activities or begin with a concrete pilot and afterwards develop a system.

- Difficulties were encountered in setting up regular contacts with other links in the chain. Most companies found it a little bit frightening.

- Economic benefit has not been seen so far as an important incentive to go ahead with POEM.

- Companies will integrate POEM quicker when the management has declared environment as a spearhead of the company.

- Companies expect that government and industrial branches will further stimulate the implementation of POEM by developing LCA tools which can be used easily, by streamlining information and by furnishing subsidies (3).

\section{Other IPP Instruments}

From the beginning the government of the Netherlands tried to stimulate environmentally less harmful products both from the push and the pull side. POEM is meant to change the push side and incentives for 
starting POEM are also mainly originating from the push side and very seldom from the pull side. Other instruments on the push side are eco-design, financial incentives and information systems.

On the pull side several different instruments have been developed in other to enhance the possibilities of consumers to buy green products, like ecolabels, financial subsidies for A-labelled apparatuses and an information centre for consumers. Green procurement is being endorsed vigorously as a big pull factor provided that all governmental agencies change their buying attitude towards an environmentally more conscious one.

\section{Eco-label [Milieukeur]}

Although not so successful during the first years at date more than 250 different eco-labelled products are on the market covering both the food as the non-food sector. However, the Dutch industry is reluctant to use the eco-label on a broad scale as a distinctive instrument. The European eco-label still is not successful at all.

\section{Green procurement}

The programme for a greener procurement has been started officially in 1999. Because procurement is decentralised, a system of voluntary agreements has been worked out with municipalities, provinces and ministries. About 100 of these authorities have signed such an agreement yet. In the mean time environmental criteria for different products groups have been developed with the help of all parties involved and made public on a web site. The main problem of green procurement in most agencies is the organisation of procurement.

\section{R\&D infrastructure}

Moreover, a very broad R\&D infrastructure has been build up concerning environmental aspects of the product system, for example

- the faculty Design for Sustainability at the Technical University of Delft;

the new institute Kathalys, set up by the Technical University of Delft and TNO with the purpose to investigate - in close co-operation with entrepreneurs - new concepts of product systems concerning e.g. the kitchen, household, or transport system;

and just recently a National Institute on Sustainable Development (NIDO) set up to organise technology breakthroughs in close co-operation with industry, knowledge institutes and government.

\section{Eco-design}

A specific programme for small and medium sized enterprises (SME's) is one out of many activities in the field of eco-design that has been financially stimulated by the Ministries of Economics and the Environment. About 1000 SME's have been advised on the possibilities to change their product with economic and environmental gain. The evaluation of this programme that ended in 1998 showed the long time gap between advice and real implementation. Other aspects seem to be more important like the moment of investment or the willingness to enter new markets (4).

\section{LCA and Eco-indicator}

Very recently a renewed method has been published (Eco-Indicator 99) to be used by product designers to weigh the outcome of Life Cycle Assessment (LCA) resulting in an ecological indicator per process or material. In a manual for designers eco-indicators of more than 200 materials and processes are calculated based on general accessible LCA data (5).

In order to strengthen sustainable building a process has been started to develop a method of drawing up a building's material-based environmental profile (MEPB) derived from the existing, performance based LCA method. The use of performance standards leaves room for innovation and creative solutions. The prototype method was finalised in July 1999. In 2000 the Minister of Housing, Spatial Planning and the Environment will decide whether to adopt new regulations on the subject. If adopted, such regulations could take effect from January 2002 (6).

\section{Information structure}

At date only the building industry has set up a regular business-to-business information exchange system about environmental issues of their products and materials. The driving force was the publication and use of a checklist of

\section{Unternebmen und Nachbaltigkeit}

ist das Thema des Informationsdienstes Ökologisches Wirtschaften 1/01

\author{
Wenn Sie potenzielle Beiträge \\ haben, wenden Sie sich bitte \\ an die Redaktion.
}

\section{politische ökologie}

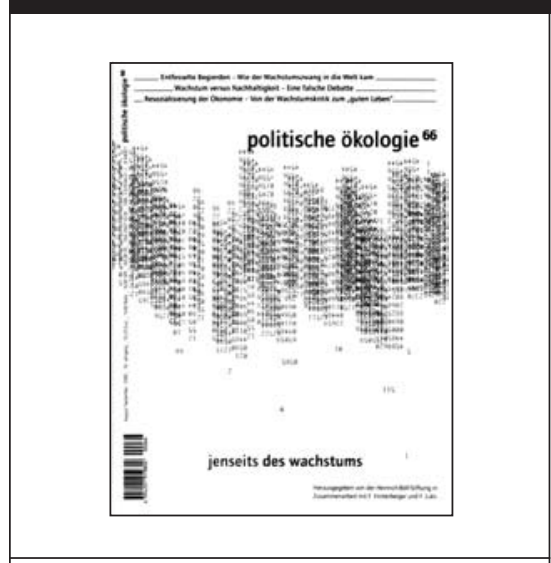

\section{Jenseits des Wachstums}

Deutschland im Jahr 2000: Wandel und Reformen werden allenthalben angemahnt, der Umbau von Industriegesellschaft und Sozialstaat beschworen, der Aufbruch in Internet-, Biotechund sonstige Zeitalter gefeiert. Wenn von Wandel die Rede ist, heißt das im Wesentlichen: Weiter so - nur besser, schneller und effizienter. Der Hinweis auf "Grenzen des Wachstums", nun bereits fast 30 Jahre alt, scheint dagegen nicht mehr relevant zu sein.

Die politische ökologie 66 bringt das Thema Wachstum wieder zurück auf die Tagesordnung. Sie versammelt prominente internationale Stimmen, die mahnen, dass das Problem nicht nur nicht gelöst ist, sondern immer drängender wird. So vielfältig wie die Diagnosen sind auch die Therapievorschläge. Das Heft gibt einen umfassenden Überblick über den Stand der Wachstumsdiskussion und zeigt, wie aktuell diese Frage nach wie vor ist. Wohin wachsen wir?

Mit Beiträgen von Fred Luks, Friedrich Hinter berger, Herman E. Daly, Gerhard Scherhorn, Elmar Altvater, Klaus Töpfer, Ernst Ulrich von Weizsäcker und anderen.

\section{www.oekom.de}

Jetzt für 19,80 Mark direkt zu bestellen bei:

pan adress

politische ökologie Leserservice

Semmelweisstr. 8

D-82152 Planegg

Fon ++49|(0)89|85709-145

Fax ++49|(0)89|85709-131 
environmentally preferable building products and materials some six years ago. Strong industrial opposition against the foundations of this list could only be successful when companies themselves knew exactly the impact on the environment of their products. After a five-yearsperiod of development an independent organisation has been set up by the building sector to verify the LCA-based information exchange. The environmental information collected can and will be used either for decisions in the next phases of the chain or as input for the material requirements in the building decree. At date more than 100 companies have signed licensees to be allowed to use the registered MRPI [ = Milieu Relevante Product Informatie] logo. In some other branches information about environmental issues of products has been collected at branch level. POEM has been a major driving force for such information systems. And industrial sectors with information systems tend to develop POEM more easily than branches without any information system.

Information for consumers is collected and assessed by MilieuCentraal. This independent organisation has been set up by the Ministry of the Environment and the assessment involves all societal actors. A web site and telephone calls are the main output of this consumer-oriented information system.

\section{IPP and consumption}

IPP is based quiet solidly on the concept of an integrated approach taking into account all environmental aspects from cradle to grave. The combination of self-regulation and an integrated approach leaves a maximum of flexibility for companies to choose the direction of product improvements. IPP has gradually been embedded very well in sustainable consumption policy. The philosophy behind is a balanced strategy in which both producers and consumers take part, with retailers as intermediaries. Orchestrated action on both sides of the chain can amplify each other and assure sustainable production and consumption patterns.

The environmental impact of important domains of consumption has been assessed roughly during the last two years, such as food, building, personal care, recreation, clothing. Based on this assessment the most important environmental aspects have been formulated and set on the agenda of a specific product chain group, in which all chain actors are gathered.

\section{Towards IPP routinely}

Integrated Product Policy is generally accepted as a necessary stage in the development towards sustainable enterpreneurship. It is well understood that continuously improving products and services can bring enormous environmental and sometimes also economic improvements. Industry, consumer organisations, retail organisations and environmental NGO's do readily support these thoughts and are willing to co-operate in implementation, although there is a basic difference between industry and NGO's about the banning or sun-setting of certain products or certain materials.

Only a small part of industry has incorporated the principles of IPP in their managerial decisions. Many more enterprises include environmental aspects in the development of new products and many thousand companies are working out environmental aspects of their products because of e.g. the demand of environmental information by purchasers or consumers. In total, most companies have not yet taken up the first step into the direction of IPP.

The development of IPP in the Netherlands has come to a stage that pilots and experiments are not enough any longer to disseminate the thoughts of IPP. Industry and government together have the intention to better implement IPP in companies and branches on the basis of a concerted programme for the coming four years. Because of the great differences between products this programme can only be successful if flexibility is big enough, if companies themselves can work out IPP, and if some basic criteria are fulfilled. Branches are expected to act as the most important intermediaries because they can transform general principles and criteria into applicable and practical guidelines for IPP for their members.

\section{Conclusion}

In the Netherlands the overall goal of IPP has been unchanged since the beginning of the nineties: a process of continuous and systematical improvement of products and services to be established by industry itself. The instrumental approach of government has changed dramatically. Starting with information as the main instrument integrated product policy was confronted with a lot of opposition. The switch to POEM as an instrument fitting better with the companies' philosophy yielded a swing towards general acceptance of integrated product policy among the main industrial representatives. The next phase of IPP is coming up after a three-yearsperiod of development of this rather new but very promising instrument. The process of spreading the introduction of POEM is now under way in close co-operation with industry. Introduction of IPP should become a normal activity in every company in the next decade.

At this moment IPP is still not a routine job for most of the Dutch companies. It appeared to take much more time than expected between the first acknowledgement of a company of IPP and the adjustment of their products. This time lag has also been experienced with the introduction of eco-design in SME's and an information exchange system in the construction sector.

\section{References}

(1) Dutch Government: Policy document on Products and the Environment. The Hague 1993.

(2) Cf. Klinkers, L./ van der Kooy, W./ Wijnen, H.: Product oriented environmental management provides new opportunities and directions for speeding up environmental performance. In: Greener Management International, Issue 26, Summer 1999, pp. 91-108;

Berkel, R. van/ van Kampen, M./ Kortman, J.: Opportunities and constraints for Product-Oriented Environmental Management Systems. In: Journal of Cleaner Production, Vol. 7 (1999), pp. 447-455

(3) The results of the evaluation have been published in august 2000 and will be translated in English in due time. (4) Tukker, A./ Haag, E. (eds.): Eco-design: European state of the art. ESTO project report prepared for the European commission/ IPTS Sevilla, April 2000.

(5) Ministry of the Environment of the Netherlands: Manual for designers, Eco-Indicator '99, The Hague. In 2001 also a renewed manual for detailed and rough LCA's will be published.

(6) Scholten N.: LCA as Performance Requirement in the Dutch Building Decree by 2001. In: Lacasse, M.A. et al. (eds.): Durability of Building Materials \& Components 8, Volume 3, NRC Research Press, Ottawa 1999, pp. 1939-1947.

Der Autor
Henk Wijnen ist Koordinator für Produktpolitik im
Niederländischen Ministerium für Wohnungswesen,
Raumplanung und Umwelt (VROM).
Kontakt: Tel.0031-70-339-4229, Fax -1293,
E-mail: henk.wijnen@minvrom.nl


(c) 20I0 Authors; licensee IÖW and oekom verlag. This is an article distributed under the terms of the Creative Commons Attribution Non-Commercial No Derivates License (http://creativecommons.org/licenses/by-nc-nd/3.o/), which permits unrestricted use, distribution, and reproduction in any medium, provided the original work is properly cited. 